\title{
Bioactive Peptides; Physiological Benefits and Commercial Applications
}

\author{
Muhammad Farhan Jahangir Chughtai*, Tariq Mehmood, Atif Liaqat and Adnan Khaliq \\ Department of Food Science and Technology, Khwaja Fareed University of Engineering and Information Technology, Pakistan
}

Submission: May 06, 2019; Published: May 29, 2019

*Corresponding author: Muhammad Farhan Jahangir Chughtai, Department of Food Science and Technology, Khwaja Fareed University of Engineering and Information Technology, Rahim Yar Khan, Pakistan

\begin{abstract}
Milk and milk related products are strongly considered as rich source of bioactive peptides which have potential to be used as ingredients in nutraceutical foods. Dairy peptides play a key role to increase the antioxidant efficiency in multiplication order. These health promoting components have beneficial effects on health as antioxidant, antimicrobial, antihypertensive, anticancer etc. Enzymatic hydrolysis action can easily produce peptides during gastrointestinal digestion that can be facilitated by utilization of fermented dairy products like cheese, sour milk and yogurt. Milk related bioactive peptides are getting attention in context of commercial interest. On commercial scale, emerging techniques e.g. chromatography and membrane separation are applied in the production of milk derived bioactive peptides. In industries, to produce such ingredients, techniques like ultrafiltration and nanofiltration are also employed. Production of such type of peptides from high protein raw material can be uplifted to commercial level using controlled fermentation with LAB in bioreactor. In future, isolation of peptides from microbial strains recombined technology and production of explicit strains are likely to be employed.
\end{abstract}

Keywords: Bioactive peptides; Commercial applications; Health benefits; Digestion

\section{Introduction}

Bioactive peptides having diverse functional activities are found in numerous milk products including fermented milk and different types of cheese. Production of bioactive peptides during fermentation of milk using starter cultures has been reported in various studies [1-4]. These peptides are the fragments of proteins which are produced upon cleavage or modification of the parent protein and comprised of 2-20 amino acids [5]. Though bioactive peptides may be produced upon hydrolysis of proteins $[6,7]$ lactoferrin, hormones, growth factors lysozyme, immunoglobulins etc. are the naturally occurring bioactive molecules in milk [7-9]. As a part of the parent proteins, these peptides are inactive which may be released by the action of the digestive enzymes while passing through the GI tract or during fermentation and ripening processes $[10,11]$.

\section{Health Promoting Effects}

In the human body, these bioactive peptides perform many biological functions such as on nervous, digestive, immune $[5,12]$, cardiovascular, endocrine systems [11,13], and exert a number of health beneficial effects including anti-oxidative, antithrombotic, antihypertensive, antimicrobial, anticancer and immunomodulation, which have been well documented in a number of studies $[5,7,14]$. Due to these health promoting properties, these bioactive molecules may be added to the functional foods [7].

\section{Bioactive Peptides Digestion and Absorption}

A number of milk proteins and peptides from gastrointestinal hydrolysis have been investigated by in vitro trials. It is a stepwise process like breakdown with pepsin and pancreatic enzymes. It is concluded that gastrointestinal degradation is a main step for the evaluation of biological activities according to amenable studies [15]. There are several factors like $\mathrm{pH}$, enzyme preparation, and incubation time which affects the hydrolysis of peptides [16]. Major degradation of peptides occurs in stomach and small intestine which have finger like projections. Due to these projections the surface area is increased for digestion and absorption. The metabolic activities including selection of enzymes, transporters and receptors is provided by brush border membrane that covers whole internal lumen and provide additional surface area [17]. Most of the nutrients are absorbed in small intestine in digestive track that provides obstacle to foreign substances and digestive enzymes. The diverse nature of small intestine in term of absorption is due to the epithelial cells as well as endocrine cells, cup cells, M cells, goblet cell and Paneth cells. Physiologically, function of GI tract is to digest dietary proteins and peptides into smaller units and make them small enough to 
be absorbed [18]. Peptides are hydrolyzed by multiple enzymes, known as peptidases having peptide bond specificity which promote the absorption [17]. Peptides are categorized into 2 classes: (1) exopeptidases, break the peptide linkage having link $\mathrm{N}$-terminal amino and C-terminal amino of peptide molecules and (2) endopeptidases, facilitate the breakdown of interior bond of peptide chain [18]

Acidic environment of stomach due to the presence of pepsin facilitates the initialstep of digestion which is hydrolysis of peptides. In simple words it is easy to say that initiation of digestion is take place in stomach. Pepsin, the most important endopeptidases enzymes present in stomach convert the polypeptides into oligopeptides and these oligopeptides are moved towards intestinal lumen. A few acids are released into blood stream after protein hydrolysis and others are passed to duodenum [19]. Amino acid composition and size is considered during luminal degradation [20]. At brush border carboxypeptidases and aminopeptidases are present and hydrolyze into tri, dipeptides and free amino acids [17].

\section{Absorption of Bioactive Peptides}

It is reported that specific effect is produced by physiologically active peptides which may enter directly into circulation system without degradation [20]. These may be absorbed by two different ways; (1) carrier mediated transport and (2) paracellular diffusion. These two systems are known mechanism for peptide transport through cell monolayer [21]. Transporters like PepT1 readily transport these hydrolyzed peptides through paracellular diffusion which keeps the peptides as it is instead of degenerating into subunits [22]. Moreover, vesicle-mediated transcellular transport i.e. transcytosis, may also be facilitated for the transportation of oligopeptides [23]. It is concluded that size of peptides as well as molecular weight, hydrophobicity, charge and hydrogen bonding are the key factors which affect the selection of transport method [20].

\section{Commercial Applications}

Due to health promoting effects, bioactive paptides have received the increased interest. Though milk proteins are considered to be the excellent source of these peptides, there may be other sources and methods to produce these compounds [11]. Bioactive peptides can be produced by different ways including breakdown with digestive enzymes or the enzymes from plants, fermentation (using cultures containing proteolytic bacteria) [2] and chemical synthesis [24]. The main blood protein known as serum albumin has attained attention for the production of bioactive peptides. By using different concentration of trypsin serum albumin was hydrolyzed and peptide sequences in the hydrolysates presented the following activities: inhibition (glucose regulation), DPP-IV and antioxidation angiotensinconverting enzyme (ACE) inhibition (antihypertensive activity) [25]. According to recent study 75 different types of unique peptides were unambiguously recognized by using low liquid chromatography analysis of low resolution [26].
Human diet contains major portion of cereals like rice, wheat, barley sorghum, corn, oat and rye utilized since ancient time. These cereals have higher quantities of bioactive peptides. So, the diseases like cancer, cardiovascular disease and diabetes may be controlled by the consumption of cereals according to different scientific studies. Inhibitory peptides and dipeptidyl peptides inhibitor are present in wheat and oat with hypotensive, antioxidant antithrombotic and opioid activities. On the other hand, peptidic sequences of rice and wheat protein have effect against cancer. Barley and wheat have potential activities and abundance of peptides among other cereal proteins [27]. However, more attention required to launch the mechanism to release the active peptides sequences from cereal grains. In olive oil processing industry two major types of wastes are produced; the solid waste which is combination of aqueous liquor olive pulp and stone, soft olive tissues and water added during refinement. These residues are not easily biodegradable difficult to treat and cause pollution. In recent study, antioxidant and antihypertensive potential of waste proteins from olive seed has been investigated $[28,29]$.

\section{Conclusion}

Bioactive peptides are gaining mounted attention in scientific community dur to their health promoting properties. These peptides possess antioxidant, antimicrobial, antihypertensive, immunomodulation properties etc. and have positive effects on cardiovascular, immune, nervous systems etc. Though milk is the natural and best source of these peptides, a number of other food items may also be used as a source of these peptides besides chemical synthesis. In human body, these compounds are produced in GI tract as result of digestion through peptides and other digestive enzymes or may be absorbed directly. For analysis and commercial applications, these peptides can be identified and isolated by chromatographic techniques and membrane filtration techniques. Produced in a number of ways such as by enzymes, fermentation and microbial strains, these compounds may be used as nutraceutical foods.

\section{References}

1. McCulloch SP, Reiss (2017) M.J. Bovine tuberculosis and badger control in Britain: Science, policy and politics. Journal of Agricultural and Environmental Ethics 30(4): 469-484.

2. Malika Bouchez-Zacria M, Courcoul A, Durand B (2018) The Distribution of Bovine Tuberculosis in Cattle Farms Is Linked to Cattle Trade and Badger-Mediated Contact Networks in South-Western France, 20072015. Front Vet Sci 5: 173.

3. Guta S, Casal J, Napp S, Saez JL, Garcia-Saenz A, et al. (2014) Epidemiological investigation of bovine tuberculosis herd breakdowns in Spain 2009/2011. Plosone 9: e104383.

4. Cowie CE, Beck BB, Gortazar C, Vicente J, Hutchings MR, et al. (2014) Risk factors for the detected presence of Mycobacterium bovis in cattle in south central Spain. Eur J Wildl Res 60: 113-123.

5. Roper T Badger (2010) Collins New Naturalist, London, UK.

6. Godfray HCJ, Donnelly CA, Hewinson RG, Winter M, Wood JLN (2018) Bovine TB Strategy Review. October 2018 Defra, London, UK. 
7. Department for Environment, Food and Rural Affairs (2011) Bovine Tuberculosis Eradication Programme for England, UK.

8. Department for Environment, Food and Rural Affairs (2014) The Strategy for achieving Officially Bovine Tuberculosis Free status for England, UK.

9. Department for Environment, Food and Rural Affairs (2017) Guidance to Natural England Licenses to kill or take badgers for the purpose of preventing the spread of bovine TB under section 10(2)(a) of the Protection of Badgers Act 1992.

10. Brunton LA, Donnelly CA, O'Connor H, Prosser A, Ashfield S, et al. (2017) Assessing the effects of the first 2 years of industry-led badger culling in England on the incidence of bovine tuberculosis in cattle in 2013-2015. Ecol Evol p. 1-18.

11. Bourne J, Donnelly C, Cox D, Gettinby G, McInerney J, et al. (2007) Bovine TB: The Scientific Evidence. A Science Base for a Sustainable Policy to Control TB in Cattle. Final Report of the Independent Scientific Group on Cattle TB presented to the Secretary of State for Environment, Food and Rural Affairs the Rt Hon David Miliband MP pp. 287.

12. Donnelly CA, Woodroffe R, Cox DR, Bourne FJ, Cheeseman CL, et al. (2006) Positive and negative effects of widespread badger culling on tuberculosis in cattle. Nature 439(7078): 843-846.

13. Donnelly CA, Wei G, Johnston WT, Cox DR, Woodroffe R, et al. (2007) Impacts of widespread badger culling on cattle tuberculosis: concluding analyses from a large-scale field trial. Int J Infect Dis 11(4): 300-308.

14. Krebs J, Anderson R, Clutton-Brock T, Morrison I, Young D, et al. (1997) Bovine tuberculosis in cattle and badgers: Report to The Rt Hon Dr Jack Cunningham MP, Ministry of Agriculture, Fisheries and Food pp. 191

15. Donnelly CA, Hone J (2010) Is there an association between levels of bovine tuberculosis in cattle herds and badgers? Stat Commun Infect Dis 2: 1 .

16. Francis J (1947) Bovine Tuberculosis, Staple Press, London, UK.

17. Zuckerman S (1980) Badgers, Cattle and Tuberculosis. HMSO, London, UK.

18. Skuce RA, Allen AR, Mc Dowell SWJ (2011) Bovine tuberculosis (TB): a review of cattle to cattle transmission, risk factors and susceptibility. Bacteriology Branch. Veterinary Sciences Division Agri food and Biosciences Institute.

19. Vernon MC (2011) Demographics of cattle movements in the United Kingdom. BMC Veterinary Research 7: 31.

20. Amos W, Brooks-Pollock E, Blackwell R, Driscoll E, Nelson-Flower M, et al. (2013) Genetic Predisposition to Pass the Standard SICCT Test for Bovine Tuberculosis in British Cattle. Plosone 38(3): e58245.

21. Karolemeas K, Donnelly CA, Conlan AJK, Mitchell AP, Clifton-Hadley RS, et al. (2012) The Effect of Badger Culling on Breakdown Prolongation and Recurrence of Bovine Tuberculosis in Cattle Herds in Great Britain. Plosone 7(12): e51342.

22. Swift BMC, Huxley JN, Plain KM, Begg DJ, de Silva K, et al. (2016) Evaluation of the limitations and methods to improve rapid phage-based detection of viable Mycobacterium avium subsp. paratuberculosis in the blood of experimentally infected cattle. Veterinary Research 12 115 .
23. Animal Plant and Health Agency (2018) Exceptional private use of nonvalidated tests for TB on cattle in England.

24. Monaghan ML, Doherty ML, Collins JD, Kazda JF, Quinna PJ (1994) The tuberculin test Veterinary Microbiology 40(1-2): 111-124

25. Nunez-Garcia J, Downs SH, Parry JE, Abernethy DA, Broughan JM, et al. (2017) Meta-analyses of the sensitivity and specificity of ante-mortem and post-mortem diagnostic tests for bovine tuberculosis in the UK and Ireland. Prev Vet Med 1(153): 94-107.

26. de la Rua-Domenech R, Goodchild AT, Vordermeier M, Clifton-Hadley R (2006) Ante mortem diagnosis of Bovine Tuberculosis: the significance of unconfirmed test reactors. Government Veterinary Journal 16(1): 65-71.

27. Goodchild AV, Downs SH, Upton P, Wood JLN, de la Rua-Domenech R (2015) Specificity of the comparative skin test for bovine tuberculosis in Great Britain. Veterinary Record 177: 258.

28. More SJ, McGrath G (2015) Randomized Badger Culling Trial: interpreting the results. Veterinary Record.

29. Jenkins HE, Woodroffe R, Donnelly CA (2008) The effects of annual widespread badger culls on cattle tuberculosis following the cessation of culling. Int J Infect Dis 12(5): 457-465.

30. Jenkins HE, Woodroffe R, Donnelly CA (2010) The duration of the effects of repeated widespread badger culling on cattle tuberculosis following the cessation of culling. Plosone 5(2): e9090.

31. Donnelly CA (2013) Results from the Randomized Badger Culling Trial based on data downloaded in July 2013. Report to Defra by Imperial College London, UK.

32. Donnelly CA, Nouvellet P (2013) The Contribution of Badgers to Confirmed Tuberculosis in Cattle in High-Incidence Areas in England. PLOS Currents Outbreaks.

33. King D (2007) Bovine tuberculosis in cattle and badgers. A report by the chief scientific advisor, Sir David King, Submitted to the Secretary of State, DEFRA, July 2007.

34. Woodroffe R, Donnelly CA, Cox DR, Bourne FJ, Cheeseman CL, et al. (2006) Effects of culling on badger Meles meles spatial organization: implications for the control of bovine tuberculosis. J Appl Ecol 43: 1-10.

35. Godfray HCJ, Donnelly CA, Kao RR, Macdonald DW, McDonald RA, et al. (2013) A restatement of the natural science evidence base relevant to the control of bovine tuberculosis in Great Britain. Proc R Soc Lond pp. 280.

36. de la Rua-Domenech R, Goodchild AT, Vordermeier HM, Hewinson RG, Christiansen KH, et al. (2006) Ante mortem diagnosis of tuberculosis in cattle: a review of tuberculin tests, y-interferon assay and other ancillary diagnostic techniques. Res Vet Sci 81: 190-210. 
This work is licensed under Creative Commons Attribution 4.0 License

DOI: 10.19080/JDVS.2019.12.555831 